\title{
FAKTOR RISIKO YANG BERHUBUNGAN DENGAN KEJADIAN PERDARAHAN POSTPARTUM PRIMER DI RUMAH SAKIT UMUM DAERAH RADEN MATTAHER PROVINSI JAMBI TAHUN 2019
}

\author{
Rosmaria Br Manik*, Yuni Susanti \\ Jurusan Kebidanan Poltekkes Kemenkes Jambi, Indonesia \\ * Korespondensi penulis: rosmaria1974@gmail.com
}

\begin{abstract}
ABSTRAK
Latar Belakang: Perdarahan postpartum primer yang terjadi dalam 24 jam pertama, merupakan penyebab tertinggi kematian ibu di Indonesia. Penelitian ini bertujuan untuk mengetahui faktor risiko yang berhubungan dengan kejadian perdarahan postpartum primer di RSUD Raden Mattaher Provinsi Jambi Tahun 2019.

Metode: Penelitian ini merupakan survey analitik dengan metode observasional menggunakan pendekatan case control. Sampel kasus sebanyak 48 diambil secara total sampling yang merupakan jumlah kasus yang ditemukan tahun 2013-2018 dan sampel kontrol sebanyak 48 diambil menggunakan teknik purposive sampling dengan perbandingan jumlah 1:1. Pengumpulan data dilakukan dengan cara dokumentasi. Analisis data dilakukan secara univariat dan bivariat.

Hasil: Sebagian responden berada pada umur dan paritas yang berisiko serta mengalami anemia dan hasil bivariat menunjukkan umur ( $p$-value $=0,002$ dan $\mathrm{OR}=4,109)$, paritas $(p$-value $=0,000$ dan $\mathrm{OR}=7,400)$, anemia $(p$-value $=0,000$ dan $\mathrm{OR}=14,224$ ) memiliki hubungan bermakna dengan kejadian perdarahan postpartum primer.

Kesimpulan: Umur, paritas dan anemia merupakan faktor yang berhubungan secara signifikan dengan kejadian perdarahan postpartum primer di RSUD Raden Mattaher Provinsi Jambi.
\end{abstract}

Kata Kunci: faktor risiko; perdarahan postpartum primer

\section{RISK FACTOR RELATED TO PRIMARY POST PARTUM HEMORRHAGE AT RADEN MATTAHER REGIONAL HOSPITAL JAMBI PROVINCE IN 2019}

\begin{abstract}
Background: Primary postpartum hemorrhage that occurs within the first 24 hours is the highest cause of maternal mortality in Indonesia. This study aimed to determine the risk factors associated with the incidence of primary postpartum hemorrhage at Raden Mattaher Regional Hospital Jambi Province in 2019.

Methods: This was an analytic survey with observational method using a case control approach. A total of 48 of primary post partum hemorrhage case were included as the case samples using total sampling technique and 48 control samples were recruited using purposive sampling with a ratio of 1: 1. Data collection was done by documentation followed by univariate and bivariate data analysis.

Results: The results of the univariate study showed that some of the respondents' age and parity status were at risk of anemia. Bivariate results showed that age ( $p$-value $=0.002$ and $O R=4.109)$, parity $(p$-value $=0.000$ and $O R=$ $7.400)$ and anemia $(p$-value $=0,000$ and $O R=14,224)$ were associated with the incidence of primary postpartum hemorrhage..

Conclusion: Age, parity and anemia was a significant factors acosiated with the incidence of primary postpartum hemorrhage at Raden Mattaher Regional Hospital Jambi Province
\end{abstract}

Keyword: risk factors; primary postpartum hemorrhage 


\section{PENDAHULUAN}

Perdarahan postpartum primer atau primary postpartum hemorrhage ( $\mathrm{PPH})$ merupakan perdarahan dari daerah genital wanita lebih dari $500 \mathrm{ml}$ paska persalinan normal atau lebih dari $1000 \mathrm{ml}$ paska persalinan cesarean section yang terjadi dalam 24 jam pertama dan biasanya disebabkan oleh atonia uteri, perineal trauma, retensio plasenta, dan gangguan pembekuan darah. ${ }^{1}$ Word Health Organization (WHO) memperkirakan sekitar $10 \%$ kelahiran hidup mengalami perdarahan postpartum. ${ }^{2}$ Sekitar 3-5\% pasien obstetrik berpeluang mengalami perdarahan postpartum serta merupakan salah satu penyebab kematian wanita paska melahirkan di seluruh dunia. ${ }^{3}$

Word Health Organization (WHO) mengatakan sebanyak 99\% kematian ibu akibat masalah persalinan atau kelahiran terjadi di negara berkembang merupakan yang tertinggi dengan 450 kematian ibu per 100.000 kelahiran bayi hidup jika dibandingkan dengan rasio kematian ibu di 9 negara maju dan 51 negara berkembang. Perdarahan pasca persalinan menempati persentase tertinggi penyebab kematian ibu $28 \%{ }^{2}$

Profil Kesehatan Indonesia tahun 2016 menyebutkan perdarahan postpartum (32\%) merupakan penyebab tertinggi kematian ibu, yang menjadi masalah hampir di semua wilayah di Indonesia adalah ibu hamil dan bersalin di bawah usia 20 tahun. Kematian ibu dapat terjadi saat hamil, bersalin atau 42 hari setelah persalinan dengan penyebab yang berhubungan langsung atau tidak langsung terhadap persalinan. Perdarahan postpartum merupakan penyebab utama kematian maternal diseluruh dunia dan menyebabkan kematian 127.000 maternal dari 14 juta kasus perdarahan yang terjadi setiap tahunnya ${ }^{4}$

Direktorat Jenderal Kesehatan Masyarakat Kementerian Kesehatan menyatakan bahwa Angka Kematian Ibu (AKI) berdasarkan Survey Penduduk Antar Sensus tahun 2015 yaitu 305 kematian ibu/ 100.000 kelahiran hidup. Kematian Ibu terjadi dengan penyebab diantaranya gangguan hipertensi sebanyak $33,07 \%$, perdarahan obstetrik $27.03 \%$, komplikasi non obstetrik $15.7 \%$, komplikasi obstetrik lainnya $12.04 \%$, infeksi pada kehamilan $6.06 \%$ dan penyebab lainnya $4.81 \%$. Indonesia menargetkan penurunan angka tersebut menjadi 242 pada tahun $2024 .{ }^{5}$

Adapun faktor risiko yang menyebabkan terjadinya perdarahan postpartum primer menurut Prawirohardjo adalah umur, paritas, anemia dan kekurangan gizi. Umur mempunyai pengaruh terhadap kemungkinan terjadinya peningkatan jumlah darah pada kala III dan IV, perdarahan postpartum lebih banyak pada umur $>35$ tahun. ${ }^{6}$ Wanita hamil yang berusia lebih dari 5 tahun berisiko 7 kali lebih tinggi mengalami perdarahan postpartum. ${ }^{7}$

Kehamilan pada ibu multigravida dapat mengalami risiko terjadinya perdarahan postpartum dikarenakan adanya gangguan keelastisan otot otot uterus untuk berkontraksi dan mengalami kerusakan pembuluh darah dinding uterus yang akan mempengaruhi sirkulasi nutrisi kejanin ${ }^{7}$

Ibu yang hamil dengan anemia saat postpartum akan mengalami atonia uteri. Hal ini disebabkan karena oksigen yang dikirim ke uterus kurang. Jumlah oksigen dalam darah yang kurang menyebabkan otot-otot uterus tidak berkontraksi dengan adekuat sehingga timbul atonia uteri yang mengakibatkan perdarahan banyak. ${ }^{8}$

Angka kejadian perdarahan post partum yang tinggi di Indonesia yaitu $5-15 \%$ selain disebabkan oleh atonia uteri(50-60\%), retention placenta(16-17\%), laserasi jalan lahir(4-5\%) dan kelain darah, dapat pula disebabkan oleh penyebab tidak langsung yaitu anemia ibu hamil(sebanyak 5,6\%). ${ }^{9}$

Berdasarkan hasil survei, dari data rekam medik di Rumah Sakit Umum Daerah Raden Mattaher Provinsi Jambi jumlah kejadian perdarahan post partum primer pada tahun 2013 sebanyak (1,4\%) 13 kasus, tahun $2014(1,1 \%) 10$ kasus, tahun $2015(0,4 \%) 4$ kasus, tahun 2016 $(0,3 \%) 3$ kasus, tahun 2017 (2\%) 18 kasus. Jika dijumlahkan dari tahun 2013-2018 terdapat sebanyak 48 kasus $(5,2 \%)$ perdarahan postpartum dari 884 ibu bersalin. Atonia uteri dan retensio plasenta merupakan penyebab terbanyak perdarahan post partum primer di Rumah Sakit Umum Raden Mattaher. Berdasarkan kelompok umur, paritas dan status anemia, kejadian perdarahan postpartum banyak ditemukan pada kelompok yang berisiko. ${ }^{10}$

Berdasarkan data tersebut, maka penelitian ini dilakukan untuk mengetahui faktor-faktor risiko yang berhubungan dengan kejadian postpartum primer di Rumah Sakit Umum Daerah Raden Mattaher Provinsi Jambi tahun 2019.

\section{METODE}

Penelitian ini merupakan penelitian survey analitik dengan menggunakan metode observasional dengan pendekatan cross sectional yang bertujuan untuk mengetahui 
faktor risiko yang berhubungan dengan kejadian perdarahan postpartum primer di RSUD Raden Mattaher Provinsi Jambi Tahun 2019. Populasi untuk kasus pada penelitian ini adalah ibu yang mengalami perdarahan postpartum primer di RSUD Raden Mattaher Provinsi Jambi tahun 2013-2019 berjumlah (5,2\%) 48 orang ibu. Populasi untuk kontrol pada penelitian ini adalah seluruh ibu yang tidak mengalami perdarahan post partum primer di RSUD Raden Mattaher Provinsi Jambi tahun 2013-2019. Adapun sampel untuk kelompok kasus adalah ibu yang mengalami perdarahan post partum primer dengan jumlah 48 orang ibu dan sampel kontrol adalah ibu yang tidak mengalami perdarahan post partum primer dengan jumlah 48 orang ibu. Teknik pengambilan sampel kasus menggunakan total sampling sedangkan teknik pengambilan sampel kontrol menggunakan purposive sampling dengan perbandingan jumlah 1:1. Metode Pengumpulan data dalam penelitian ini adalah studi dokumentasi.

Analisis data yang digunakan adalah analisis univariat dan bivariate.

\section{HASIL DAN PEMBAHASAN}

Hasil penelitian yang menghubungkan antara umur dan kejadian perdarahan postpartum di RSUD Raden Mattaher Provinsi Jambi Tahun 2019 dapat dilihat pada tabel 1 .

Tabel 1. Hubungan Umur Dengan Kejadian Perdarahan Postpartum Primer di RSUD Raden Mattaher Provinsi Jambi Tahun 2019.

\begin{tabular}{|c|c|c|c|c|c|c|c|}
\hline \multirow[t]{3}{*}{ Umur } & \multicolumn{4}{|c|}{$\begin{array}{l}\text { Kejadian Perdarahan } \\
\text { Postpartum Primer }\end{array}$} & \multirow{2}{*}{\multicolumn{2}{|c|}{ Total }} & \multirow[t]{3}{*}{$\begin{array}{c}\text { OR } \\
95 \% \text { CI value }\end{array}$} \\
\hline & \multicolumn{2}{|c|}{ Kasus } & \multicolumn{2}{|c|}{ Kontrol } & & & \\
\hline & $\mathbf{J m l}$ & $\%$ & Jml & $\%$ & jml & $\%$ & \\
\hline Berisiko & 29 & 60,4 & 13 & 27 & 42 & 43,75 & 4,109 \\
\hline $\begin{array}{l}\text { Tidak } \\
\text { berisiko }\end{array}$ & 19 & 39,6 & 35 & 73 & 54 & 56,25 & $9,713)$ \\
\hline Jumlah & 48 & 100 & 48 & 100 & 96 & 100 & \\
\hline
\end{tabular}

Hasil penelitian menunjukkan umur yang berisiko memiliki hubungan yang signifikan dengan kejadian perdarahan postpartum di RS Raden Mattaher tahun 2019. Menurut Fauziyah, umur mempunyai pengaruh terhadap kemungkinan terjadinya peningkatan jumlah darah pada kala III dan IV yang mengakibatkan terjadinya perdarahan postpartum, dengan umur ibu $>35$ tahun yang paling banyak mengalami perdarahan postpartum ${ }^{11}$
Hal ini sejalan dengan penelitian terdahulu di Samarinda yang menunjukkan bahwa sebagian besar ibu yang mengalami perdarahan postpartum berada pada usia $<20$ tahun dan $>35$ tahun. ${ }^{12}$

Studi metaanalisis mengenai hubungan usia dengan kejadian perdarahan postpartum di berbagai negara mendapatkan hasil yang berbeda beda serta menggunakan metode penelitian juga kriteria inklusi dan eksklusi yang beragam dalam pengelompokan usia yang diteliti. Frekuensi kejadian perdarahan postpartum primer ditemukan lebih tinggi pada ibu hamil berusia 35 tahu atau lebih. Namun beberapa penelitian juga menemukan kejadian yang tingggi pada usia di bawah 35 tahun. ${ }^{13}$

Pengaruh usia terhadap risiko perdarahan postpartum dapat terjadi apabila ibu yang hamil berusia dibawah 20 tahun maka otot rahim masih terlalu lemah dalam proses involusi sedangkan pada umur $>35$ tahun elastisitas otot panggul dan alat reproduksinya sudah menurun, sehingga memungkinkan memiliki komplikasi yang berkembang sekitar waktu kelahiran. ${ }^{8}$

Hubungkan antara status paritas dan kejadian perdarahan postpartum di RSUD Raden Mattaher Provinsi Jambi Tahun 2019 dapat dilihat pada tabel 2 .

Tabel 2. Hubungan Paritas Dengan Kejadian Perdarahan Postpartum Primer di RSUD Raden Mattaher Provinsi Jambi Tahun 2019

\begin{tabular}{|c|c|c|c|c|c|c|c|c|}
\hline \multirow[t]{3}{*}{ Paritas } & \multicolumn{4}{|c|}{$\begin{array}{c}\text { Kejadian Perdarahan } \\
\text { Postpartum Primer }\end{array}$} & \multirow{2}{*}{\multicolumn{2}{|c|}{ Total }} & \multirow[t]{3}{*}{$\begin{array}{c}\text { OR } \\
95 \% \mathrm{CI}\end{array}$} & \multirow[t]{3}{*}{$\begin{array}{c}p- \\
\text { value }\end{array}$} \\
\hline & \multicolumn{2}{|c|}{ Kasus } & \multicolumn{2}{|c|}{ Kontrol } & & & & \\
\hline & $\mathbf{J m l}$ & $\%$ & Jml & $\%$ & jml & $\%$ & & \\
\hline Berisiko & 33 & 68,7 & 11 & 22,9 & 44 & 45,8 & 4,109 & 0,002 \\
\hline $\begin{array}{l}\text { Tidak } \\
\text { berisiko }\end{array}$ & 15 & 31,3 & 37 & 77,1 & 52 & 54,2 & $\begin{array}{l}(1, / 39- \\
9,713)\end{array}$ & \\
\hline Jumlah & 48 & 100 & 48 & 100 & 96 & 100 & & \\
\hline
\end{tabular}

dilakukan didapatkan hasil analisis univariat menunjukkan bahwa pada kasus ibu yang mengalami perdarahan postpartum primer sebagian berada pada paritas yang berisiko (1 dan > 3) dan pada kontrol ibu yang tidak mengalami perdarahan postpartum primer sebagian besar berada pada paritas yang tidak berisiko (2-3). Berdasarkan hasil penelitian ini diperoleh hasil analisis bivariat menunjukkan bahwa ada hubungan yang signifikan ( $p$ value $=$ $0,002)$ antara paritas dengan kejadian perdarahan postpartum primer, ibu dengan paritas berisiko mempunyai peluang untuk terjadi perdarahan 
postpartum primer dibandingkan dengan paritas ibu yang tidak berisiko.

Hal ini juga sejalan dengan penelitian yang dilakukan di Bandung, Lampung dan Purwodadi. ${ }^{14-16}$ Semakin tinggi angka paritas akan membuat kemampuan uterus untuk kembali ke bentuk semula lebih sulit sehingga berisiko terjadi perdarahan postpartum. ${ }^{14}$ Risiko dari perdarahan post partum pada ibu hamil multipara terjadi karena seringnya otot uterus diregangkan sehingga dindingnya menipis dan kontraksinya melemah. ${ }^{15}$ Sementara pada paritas yang rendah yaitu paritas 1, risiko perdarahan postpartum dapat terjadi akibat ketidaksiapan ibu dalam menghadapi persalinan. ${ }^{16}$ Perdarahan postpartum berisiko terjadi 7 kali lebih tinggi pada ibu hamil dengan paritas $>4 .^{14}$

Hal ini berkaitan dengan pendapat Padila yaitu paritas 1 dan paritas $>3$ mempunyai angka kematian maternal lebih tinggi, dan cendrung lebih tinggi menyebabkan kematian maternal. Risiko pada paritas 1 dapat ditangani dengan asuhan obstetri lebih baik, sedangkan risiko pada paritas tinggi dapat dikurangi atau dicegah dengan keluarga berencana. ${ }^{17}$

Paritas yang tinggi dapat mengakibatkan semakin melemahnya kontraksi atau atonia. Kegagalan myometrium berkontraksi segera setelah persalinan dapat menyebabkan uterus mengalami relaksasi penuh, melebar, lembek dan tidak mampu menjalanjan fungsi oklusi pembuluh darah yang dapat berakibat perdarahan. ${ }^{18}$

Hubungkan antara status anemia dan kejadian perdarahan postpartum di RSUD Raden Mattaher Provinsi Jambi Tahun 2019 dapat dilihat pada tabel 3 .

Tabel 3. Hubungan Anemia Dengan Kejadian Perdarahan Postpartum Primer di RSUD Raden Mattaher Provinsi Jambi Tahun 2019

\begin{tabular}{|c|c|c|c|c|c|c|c|c|}
\hline \multirow[t]{3}{*}{ Anemia } & \multicolumn{4}{|c|}{$\begin{array}{c}\text { Kejadian Perdarahan } \\
\text { Postpartum Primer }\end{array}$} & \multirow{2}{*}{\multicolumn{2}{|c|}{ Total }} & \multirow[t]{3}{*}{$\begin{array}{c}\text { OR } \\
95 \% \mathrm{CI}\end{array}$} & \multirow[t]{3}{*}{$\begin{array}{c}p- \\
\text { value }\end{array}$} \\
\hline & \multicolumn{2}{|c|}{ Kasus } & \multicolumn{2}{|c|}{ Kontrol } & & & & \\
\hline & Jml & $\%$ & Jml & $\%$ & jml & $\%$ & & \\
\hline Berisiko & 41 & 85,4 & 14 & 29,2 & 55 & 57,3 & 14,224 & 0,000 \\
\hline $\begin{array}{l}\text { Tidak } \\
\text { berisiko }\end{array}$ & 7 & 14,6 & 34 & 70,8 & 41 & 42,7 & $\begin{array}{l}(5,156- \\
39,243)\end{array}$ & \\
\hline Jumlah & 48 & 100 & 48 & 100 & 96 & 100 & & \\
\hline
\end{tabular}

Berdasarkan penelitian yang telah dilakukan didapatkan hasil bahwa anemia memiliki hubungan signifikan $(p$ value $=0,000)$ dengan kejadian perdarahan postpartum di RS Raden Mattaher Jambi.
Hasil penelitian ini mendukung hasil penelitian terdahulu di Lampung yang juga menunjukkan hasil serupa. Anemia terutama anemia berat sangat membahayakan jiwa ibu maupun janin yang dikandungnya. Jika ibu hamil kekurangan zat besi maka oksigen yang beredar di dalam darah terutama daerah uterus juga berkurang sehingga dapat mempengaruhi kemampuan uterus berrkontraksi setelah persalinan. Hal ini dapat berisiko terjadinya perdarahan postpartum. ${ }^{15}$

Menurut Manuaba ibu yang mengalami anemia akan terjadi penurunan kadar oksigen dalam darah sehingga penurunan ini menggangu proses pemulihan uterus sehingga terjadi atonia uteri dan mengaibatkan terjadi perdarahan postpartum. ${ }^{9}$

Menurunnya oksigenasi, glukosa dan nutrisi esensial menyebabkan metabolisme otot otot uterus mengalami gangguan sehingga berisiko terjadi gangguan kontraksi miometrium pasca persalinan. Untuk dapat berkontraksi otot rahim membutuhkan suplai energi dan oksigen. Kurangnya asupan tersebut membuat otot tidak dapat berkonstraksi secara adekuat yang pada akhirnya menimbulkan risiko perdarahan postpartum. ${ }^{19}$

\section{KESIMPULAN}

Penelitian ini menunjukkan bahwa usia, paritas dan anemia berhubungan secara signifikan dengan kejadian perdarahan postpartum primer di Rumah Sakit Umum Daerah Raden Mataher provinsi Jambi tahun 2019.

\section{UCAPAN TERIMA KASIH}

Penulis mengucapkan terima kasih kepada bagian rekam medik RSUD Raden Mattaher Jambi.

\section{DAFTAR PUSTAKA}

1. Ngwenya S. Postpartum hemorrhage: Incidence, risk factors, and outcomes in a low-resource setting. Int J Womens Health. 2016; 8:647-650.

2. WHO. Buku Saku Pelayanan Kesehatan ibu di fasilitas Kesehatan Dasar dan rujukan. Jakarta. 2013.

3. Evensen, A., Anderson, J. M., \& Fontaine, P. Postpartum hemorrhage: prevention and treatment. American family physician. 2017; 95(7): 442-449. 
4. Kementrian Kesehatan Republik Indonesia. Profil kesehatan Indonesia Tahun 2016. Kementrian Kesehatan Republik Indonesia. Jakarta. 2017

5. Ditjen Kesmas. Di Rakesnas 2019, Dirjen Kesmas Paparkan Strategi Penurunan AKI dan Neonatal, http://kesmas.kemkes.go.id/portal/konten/ rilisberita/021517-di-rakesnas-2019_-dirjen-kesmaspaparkan-strategi-penurunan-aki-dan-neonatal [Diakses 10 Oktober 2019]

6. Prawirohardjo. Ilmu Kebidanan. Jakarta: PT Bina Pustaka. 2010.

7. Kebede, B. A., Abdo, R. A., Anshebo, A. A., \& Gebremariam, B. M. Prevalence and predictors of primary postpartum hemorrhage: An implication for designing effective intervention at selected hospitals, Southern Ethiopia. PloS one. 2019; 14(10).

8. Dewi. Patologi dan Patofisiologi Kebidanan. Yogyakarta: Nuha Medika. 2016.

9. Manuaba, IBG. Ilmu Kebidanan, Penyakit Kandungan dan Keluarga Berencana Untuk Pendidikan Bidan. Jakarta : EGC. 2013.

10. RSUD Raden Mattaher. Profil RSUD Raden Mattaher Jambi. 2017.

11. Fauziyah. Obstetri Patologi. Yogyakarta: Nuha Medika. 2012.

12. Rahmawati. Hubungan Usia Dengan Perdarahan Postpartum (Atonia Uteri) di Klinik Ramlah Parjib Samarinda. Jurnal Mahakam Midwifery Journal. 2017; 2(2): 60-66

13. Durmaz, Aysegul, and Nuran Komurcu. Relationship between maternal characteristics and postpartum hemorrhage: a meta-analysis study. Journal of Nursing Research. 2018; 2(5): 362-372.

14. Puspasari, H. Hubungan antara Umur dan Paritas dengan Perdarahan Postpartum di RSKIA Kota Bandung Tahun 2009-2010. Syntax Literate; Jurnal Ilmiah Indonesia. 2017; 2(7): 69-81.

15. Siagian, R., \& Sari, R. D. P. Hubungan Tingkat Paritas dan Tingkat Anemia terhadap Kejadian Perdarahan Postpartum pada Ibu Bersalin. Jurnal Majority. 2017; 6(3): 45-50.

16. Utami, W., \& Harianja, W. Y. Hubungan Antara Paritas Dan Perdarahan Postpartum. Jurnal Kesehatan Ibu dan Anak Akademi Kebidanan AnNur. 2019; 4(1): 14-19

17. Padila. Buku Ajar Keperawatan Maternitas. Yogjakarta. Nuha Medika. 2014.

18. Nyfløt, L. T. Stray-Pedersen, B., Forsen, L., \& Vangen, S. Duration of labor and the risk of severe postpartum hemorrhage: A case-control study. PloS one. 2017; 12(4).

19. Herawati, I., \& Pakpaha, Y. Hubungan Anemia Dengan Kejadian Perdarahan Postpartum Primer. Jurnal Antara Kebidanan. 2019; 2(2): 79-82. 